Key Words:

DWPF, SB6

Mercury, Ammonia

Retention:

Permanent

\title{
SLUDGE BATCH 6 PHASE II FLOWSHEET SIMULATIONS
}

\author{
D. C. Koopman \\ D. R. Best
}

MARCH 2010

Savannah River National Laboratory

Savannah River Nuclear Solutions

Aiken, SC 29808

Prepared for the U.S. Department of Energy Under Contract Number DE-AC09-08SR22470

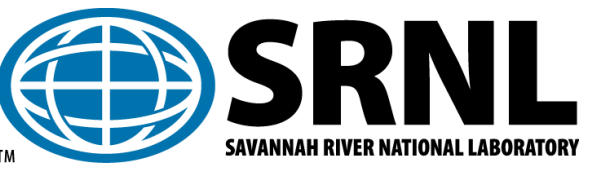




\section{DISCLAIMER}

This work was prepared under an agreement with and funded by the U.S. Government. Neither the U. S. Government or its employees, nor any of its contractors, subcontractors or their employees, makes any express or implied:

1. warranty or assumes any legal liability for the accuracy, completeness, or for the use or results of such use of any information, product, or process disclosed; or

2. representation that such use or results of such use would not infringe privately owned rights; or

3. endorsement or recommendation of any specifically identified commercial product, process, or service.

Any views and opinions of authors expressed in this work do not necessarily state or reflect those of the United States Government, or its contractors, or subcontractors.

Printed in the United States of America

Prepared for

U.S. Department of Energy 
Key Words:

DWPF, SB6

Mercury, Ammonia

Retention:

Permanent

\title{
SLUDGE BATCH 6 PHASE II FLOWSHEET SIMULATIONS
}

\author{
D. C. Koopman \\ D. R. Best
}

MARCH 2010

Savannah River National Laboratory

Savannah River Nuclear Solutions

Savannah River Site

Aiken, SC 29808 


\section{REVIEWS AND APPROVALS}

D. C. Koopman, Co-author, Process Technology Programs

Date

D. R. Best, Co-author, Process Technology Programs

Date

M. E. Stone, Peer Reviewer, Process Technology Programs

Date

C. C. Herman, Manager, Process Technology Programs

Date

S. L. Marra, Manager,

Date

Environmental \& Chemical Process Technology Research Programs

J. E. Occhipinti, Manager

Date

Waste Solidification Engineering

- ii - 


\section{TABLE OF CONTENTS}

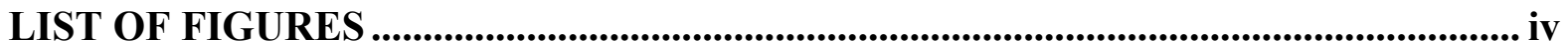

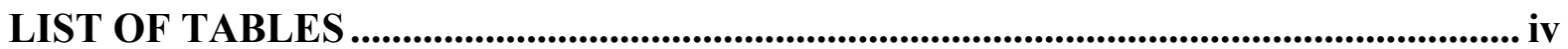

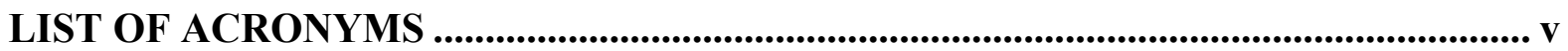

1.0 EXECUTIVE SUMMARY .......................................................................................... 1

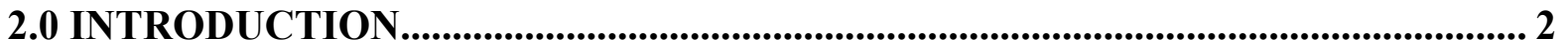

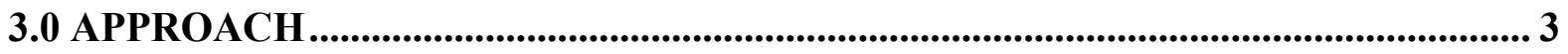

3.1 Process and Sample Analytical Methods ............................................................. 3

3.2 Chemical Process Cell Simulation Details.............................................................. 4

4.0 DISCUSSION ....................................................................................................................................6 6

4.1 Simulant and SRAT Product Characterization...................................................... 6

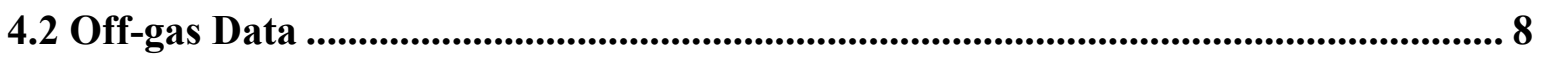

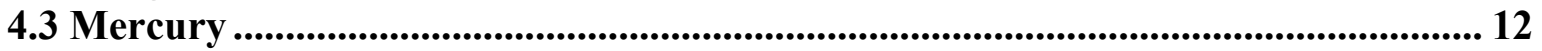

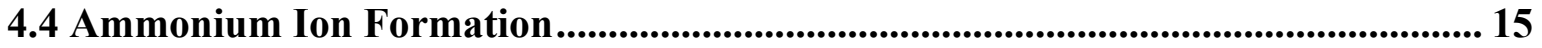

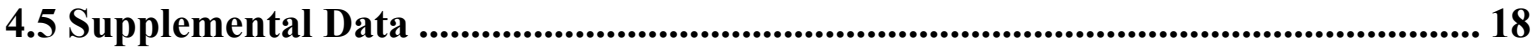

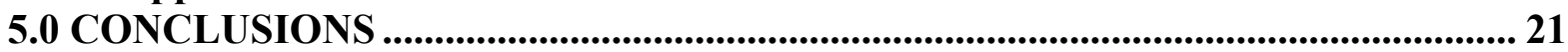

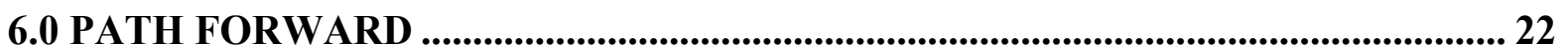

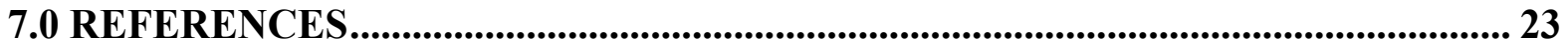




\section{LIST OF FIGURES}

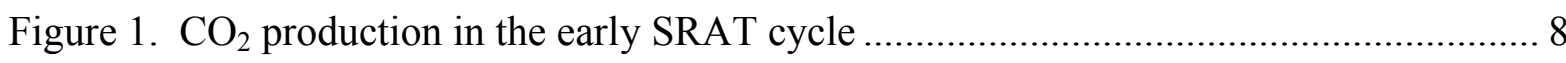

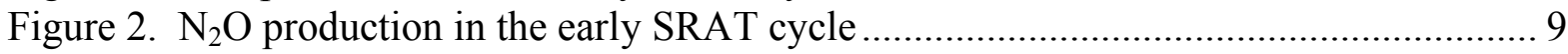

Figure 3. Complete $\mathrm{CO}_{2}$ profiles for the two SRAT cycles............................................... 10

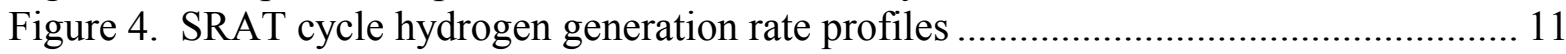

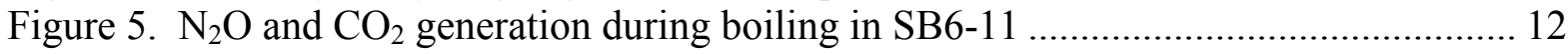

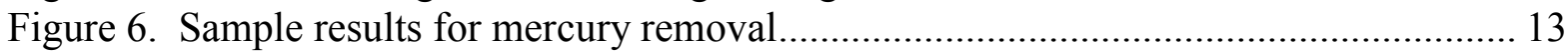

Figure 7. Signs of non-oxidative formate loss during SB6-11 ………............................... 17

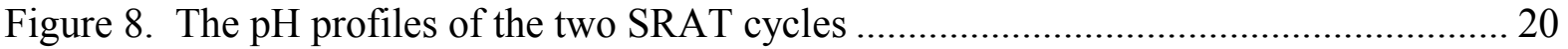

\section{LIST OF TABLES}

Table 1. Stoichiometric acid calculation results, moles acid/L trimmed slurry ....................... 4

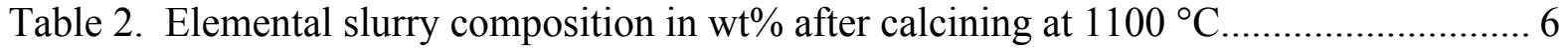

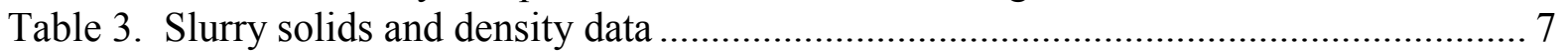

Table 4. Anion results, $\mathrm{mg}$ anion/kg slurry......................................................................... 7

Table 5. Mercury and noble metal targets, wt $\%$ in total solids................................................. 8

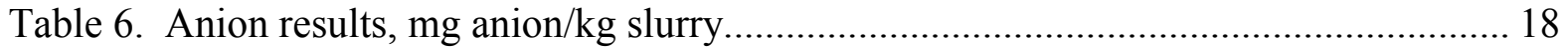

Table 7. Percentages of elements in supernate phase ………................................................ 19 


\section{LIST OF ACRONYMS}

$\begin{array}{ll}\text { ACTL } & \text { Aiken County Technology Laboratory } \\ \text { AD } & \text { Analytical Development } \\ \text { CPC } & \text { Chemical Process Cell } \\ \text { CSTR } & \text { Continuous Stirred Tank Reactor } \\ \text { CV-AA } & \text { Cold Vapor Atomic Absorption } \\ \text { DWPF } & \text { Defense Waste Processing Facility } \\ \text { FAVC } & \text { Formic Acid Vent Condenser } \\ \text { GC } & \text { Gas Chromatography } \\ \text { IC } & \text { Ion Chromatography } \\ \text { ICP-AES } & \text { Inductively Coupled Plasma-Atomic Emission Spectroscopy } \\ \text { MWWT } & \text { Mercury Water Wash Tank } \\ \text { PSAL } & \text { Process Science Analytical Laboratory } \\ \text { REDOX } & \text { Reduction/Oxidation Potential } \\ \text { SB5 } & \text { Sludge Batch 5 } \\ \text { SB6 } & \text { Sludge Batch 6 } \\ \text { SRAT } & \text { Sludge Receipt and Adjustment Tank } \\ \text { SMECT } & \text { Slurry Mix Evaporator Condensate Tank } \\ \text { SME } & \text { Slurry Mix Evaporator } \\ \text { TT\&QAP } & \text { Task Technical and Quality Assurance Plan } \\ \text { TTR } & \text { Technical Task Request }\end{array}$




\subsection{EXECUTIVE SUMMARY}

Two Sludge Receipt and Adjustment Tank (SRAT) runs were used to demonstrate that a fairly wide window of acid stoichiometry was available for processing SB6 Phase II flowsheet simulant (Tank 40 simulant) while still meeting the dual goals of acceptable nitrite destruction and controlled hydrogen generation. Phase II was an intermediate flowsheet study for the projected composition of Tank 40 after transfer of SB6/Tank 51 sludge to the heel of SB5. The composition was based on August 2009 projections. A window of about $50 \%$ in total acid was found between acceptable nitrite destruction and excessive hydrogen generation.

The Phase II composition included a very high mercury concentration of $3.5 \mathrm{wt} \%$ in the total solids combined with high noble metal concentrations. The higher acid stoichiometry test produced a significant amount of ammonium ion (at least $20 \%$ of the nitrate in the system was converted to ammonium ion). Ammonia lost in the off-gas could not be quantified with the existing equipment. Significant mercury went unaccounted for in the high acid run $(\sim 68 \%)$ and may have been lost in the off-gas or settled to the bottom of the SRAT vessel.

Over $98 \%$ of the ammonium found in the high acid run stayed in the SRAT slurry. Therefore, it is likely that most of the ammonium found so far would end up in the melter feed. The likely form is the ammonium ion rather than dissolved ammonia gas, since sustained boiling should drive off dissolved gases in the SRAT slurry. A comparison of the Phase II data with past data suggests that mercury is catalyzing or otherwise promoting formation of the ammonium ion. The lower acid stoichiometry run produced much less ammonium ion based on the FAVC condensate result, but it failed to successfully strip the mercury to $0.45 \mathrm{wt} \%$ in the SRAT product total solids during 25 hours of boiling.

The SB6 simulant was not excessively foamy, and the DWPF antifoam addition strategy was followed into boiling, however no additional antifoam was added after 8 and 16 hours of boiling. The elemental mercury collected in the Mercury Water Wash Tank (MWWT) appeared to have a surface impurity in the high acid run (only) that inhibited coalescence into a single large mass. It was also less shiny than the mass from the low acid run. The impurity may impact mercury disengagement and collection in the DWPF MWWT. The stainless steel agitator and shaft from the high acid run were a flat black color after the SRAT cycle.

Updated concentration targets will be received further into the SB6 preparation process. These will be used for a final set of SB6 flowsheet simulations (Phase III) using a revised simulant as outlined in the Task Technical and Quality Assurance Plan for SB6 flowsheet development. These tests will provide an opportunity to follow-up on some of the findings in the Phase II study. 


\subsection{INTRODUCTION}

The Defense Waste Processing Facility (DWPF) will transition from Sludge Batch 5 (SB5) processing to Sludge Batch 6 (SB6) processing in fiscal year 2010. Phase II flowsheet studies were conducted using a non-radioactive simulant of the revised SB6 composition based on the August 17, 2009 composition projections for the insoluble solids and supernate. The work was conducted to meet the objectives in the Technical Task Request (TTR) ${ }^{1}$, and followed the guidelines of a Task Technical and Quality Assurance Plan ${ }^{2}$ (TT\&QAP).

The primary justification for the Phase II testing was the determination that SB6 would contain significantly higher mercury concentrations than previous batches. Phase I flowsheet studies $^{3}$ used an assumed mercury concentration of $1.5 \mathrm{wt} \%$ in the total solids of the washed sludge (close to the SB5 concentration of $1.8 \mathrm{wt} \%$ ). Subsequent sample analyses indicated that mercury would be closer to $3.5 \mathrm{wt} \%$ in the SB6/Tank 40 blend. Additional smaller changes were made to the bulk sludge composition and noble metal concentrations relative to the Phase I composition. The main goal of Phase II was to assess the impact of mercury on the Sludge Receipt and Adjustment Tank (SRAT) chemistry and the efficiency of mercury removal during boiling. (Significant changes in the projected composition of SB6 have occurred since August 2009. The flowsheet simulant recipe was subsequently updated for the final Phase III flowsheet testing in early 2010. Phase III testing will be covered in a future report.)

A new SB6 simulant (SB6-D) was prepared for Phase II. ${ }^{4}$ The composition was based on revised projections of the blend makeup of SB6 in Tank 40 combined with updated analyses of samples from Tank 51. This simulant was used to confirm the presence of a reasonable acid addition window (range of acceptable stoichiometric factors). SRAT cycles were required to evaluate the acid window, but SME cycles were not needed. Off-gas data were obtained to evaluate hydrogen generation as well as $\mathrm{CO}_{2}$ and $\mathrm{N}_{2} \mathrm{O}$ generation. Profiles of $\mathrm{pH}$ were obtained. Samples were taken following formic acid addition to check for nitrite ion concentration and metal dissolution. Slurry samples were taken during dewatering to monitor the rate of mercury stripping. Reflux plus dewatering (boiling) lasted about 24 hours and was done at the scaled DWPF design maximum boil-up rate of 5,000 lbs/hr of steam. 
SRNL-STI-2010-00041, REV. 0

\subsection{APPROACH}

\subsection{PROCESS AND SAMPLE ANALYTICAL METHODS}

The automated data acquisition system developed for the 4-L SRAT rigs was used to collect data electronically. Data included SRAT temperature, bath temperatures for the cooling water to the SRAT condenser and Formic Acid Vent Condenser (FAVC), slurry pH, SRAT mixer speed and torque, and air and helium purge flows (He is used as an internal standard and is set to $0.5 \%$ of the nominal SRAT air purge flow). Cumulative acid addition volume data were collected from the automated dispensers using an algorithm that matches the indicated total on the dispenser. Raw GC data were generally acquired on separate computers dedicated to each instrument.

Dual column Agilent 3000A micro GC's were used on both runs. The GC's were baked out before and between runs. Column-A can collect data related to $\mathrm{He}, \mathrm{H}_{2}, \mathrm{O}_{2}, \mathrm{~N}_{2}, \mathrm{NO}$, and $\mathrm{CO}$, while column-B can collect data related to $\mathrm{CO}_{2}, \mathrm{~N}_{2} \mathrm{O}$, and water. (No evidence for $\mathrm{CO}$ generation was obtained while examining the region of the chromatogram where it would elute.) Calibrations were performed using a standard calibration gas containing $0.499 \mathrm{vol} \%$ $\mathrm{He}, 1.000$ vol $\% \mathrm{H}_{2}, 20.00$ vol $\% \mathrm{O}_{2}, 51.0$ vol $\% \mathrm{~N}_{2}, 25.0$ vol $\% \mathrm{CO}_{2}$ and 2.50 vol $\% \mathrm{~N}_{2} \mathrm{O}$. Instrument calibration was verified prior to starting the SRAT cycle. Room air was used to give a two point calibration for $\mathrm{N}_{2}$. Calibration status was rechecked following the SRAT cycle.

Process samples were analyzed by various methods. Slurry and supernate elemental compositions were determined by inductively coupled plasma-atomic emission spectroscopy (ICP-AES) at the Process Science Analytical Laboratory (PSAL). Slurry samples were calcined at $1100^{\circ} \mathrm{C}$. The main advantage of this approach is to permit easier comparisons between SRAT product elements and sludge elements. Noble metals are trimmed uniquely to each SRAT, and their concentrations are known more accurately from material balance considerations than they could be from ICP-AES analyses.

Starting sludges were submitted to Analytical Development (AD) for total inorganic carbon analysis of both the total slurry and the supernate. Starting sludges were analyzed for slurry and supernate density using the Anton-Parr instrument at ACTL. Starting sludges were titrated to $\mathrm{pH} 7$ using the ACTL auto-titrator to determine the base equivalents for input into the stoichiometric acid equation. Soluble slurry anions were determined by ion chromatography (IC) on 100-fold weighted dilutions of slurry with water followed by filtering to remove residual insoluble solids. SRAT product slurry samples and condensates from the FAVC were submitted to AD for ammonium ion analysis by cation chromatography (IC-cations).

Slurry samples were pulled periodically from the SRAT vessel for mercury analysis. These samples were pulled directly into aqua regia digestion vials. After dissolving the sludge matrix, the resulting solution was diluted to a final volume of $100 \mathrm{~mL}$. The resulting solutions were analyzed for $\mathrm{Hg}$ by both ICP-AES at PSAL and cold vapor atomic adsorption (CV-AA) by AD. SRAT dewatering condensate samples were analyzed for mercury. These 
did not require special preparations. Elemental mercury was also recovered from the process equipment. The elemental mercury was separated from the bulk of the aqueous condensate phase, the residual condensate with the mercury was allowed to air dry and/or was absorbed into paper towels, and the nearly pure, dried mercury was then weighed to determine the mass recovered. The mass of mercury recovered in this fashion constituted a lower bound on the free elemental mercury in the equipment.

\subsection{CHEMICAL PROCESS CELL SIMULATION DETAILS}

The trimmed SRAT receipt volume was about $2.75 \mathrm{~L}$. This included about $350 \mathrm{~mL}$ of water to bring the wt $\%$ total solids of SB6-D simulant into alignment with the projected total solids of SB6/Tank 40 waste of about $14.2 \mathrm{wt} \%$. The 4-L lab-scale SRAT equipment was used for these tests. Equipment was set up per the standard procedure. ${ }^{5}$ Acid calculations were based on the new Koopman minimum acid requirement equation: ${ }^{6}$

$$
\frac{\text { moles acid }}{\text { L slurry }}=\text { base equivalents }+H g+\text { soluble } T I C+1.5 *(C a+M g)+1.0 * \text { nitrite }+1.5 * M n
$$

Two stoichiometric factors were used in the acid calculations, $103 \%$ and $150 \%$. These factors were chosen to potentially ensure nitrite destruction to below $1,000 \mathrm{mg} / \mathrm{kg}$ SRAT product slurry at the low end while limiting hydrogen generation at the high end.All terms in the equation are expressed in moles of input per liter of starting sludge slurry. Acid calculations were also performed using the current DWPF algorithm for comparison: ${ }^{7}$

$$
\frac{\text { moles acid }}{\text { L slurry }}=\text { base equivalents }+2 * \text { total TIC }+0.75 * \text { nitrite }+1.2 * \mathrm{Mn}+\mathrm{Hg}
$$

This equation uses the same units for the terms as the Koopman minimum acid equation. The results of these calculations for SB6-D simulant are summarized in Table 1. The table also includes the actual acid additions and the equivalent DWPF stoichiometric factors (percent). The Koopman and Hsu-Marek (DWPF) stoichiometric acid calculations gave very similar results for SB6-D simulant.

Table 1. Stoichiometric acid calculation results, moles acid/L trimmed slurry

\begin{tabular}{|l|c|c|c|c|}
\hline $\begin{array}{l}\text { Run ID, Koopman } \\
\text { acid factor }\end{array}$ & $\begin{array}{c}\text { DWPF Eqn. } \\
\text { moles/L }\end{array}$ & $\begin{array}{c}\text { Koopman Min. } \\
\text { moles/L }\end{array}$ & $\begin{array}{c}\text { Actual addition, } \\
\text { moles/L }\end{array}$ & $\begin{array}{c}\text { Equivalent } \\
\text { DWPF factor }\end{array}$ \\
\hline SB6-10,103\% & 1.44 & 1.47 & 1.51 & $105 \%$ \\
\hline SB6-11, $150 \%$ & 1.44 & 1.47 & 2.20 & $153 \%$ \\
\hline
\end{tabular}

Total acid was partitioned between formic and nitric acids using the latest RedOx equation. ${ }^{8}$ Assumptions of $20-30 \%$ formate loss and $15 \%$ nitrite-to-nitrate conversion were made to enable this calculation to be performed without any prior experience with this simulant composition. The higher formate loss was used with the higher acid stoichiometry. This basis put the fraction of total acid that was formic acid in the range of 0.89-0.93. 
Scaled design basis DWPF SRAT/SME processing conditions were generally used. The SRAT cycle, however, did not have a heel from a prior batch.

- The SRAT air purge scaled to $230 \mathrm{scfm}$ in DWPF.

- A $200 \mathrm{ppm}$ antifoam addition was made prior to nitric acid addition.

- A 100 ppm antifoam addition was made prior to formic acid addition.

- Nitric and formic acid addition were made at $93^{\circ} \mathrm{C}$.

- Acids were added at two gallons per minute scaled from 6,000 gallons to $2.5 \mathrm{~L}$ (credit was not taken for $300 \mathrm{~g}$ of rinse water in scaling the acid flow rates).

- A $500 \mathrm{ppm}$ antifoam addition was made prior to going to boiling following acid addition.

- Boiling assumed a condensate production rate of 5,000 lbs/hr at DWPF scale.

- SRAT dewatering took about 3.5-4.5 hours to produce a product containing about 23 wt $\%$ total solids.

- Reflux followed dewatering. The end of the 21-hour reflux period defined the end of the SRAT cycle.

Several samples were taken during the SRAT cycle to monitor major reactions. It was projected that mercury might still exceed the DWPF SRAT product limit after 24 total hours at boiling due to the high starting concentration. Sampling for mercury started at the end of dewatering. Additional samples were taken $4,8,12$, and 16 hours after the start of reflux. The SRAT product slurry was also sampled for residual $\mathrm{Hg}$ while still hot and mixing. Additional SRAT product samples were taken after the product had cooled and been weighed for general compositional and solids analyses. The MWWT and FAVC were drained and weighed. The FAVC condensate was submitted for ammonium ion analysis. Subsequently, the high acid run SRAT product was also submitted for ammonium ion analysis.

A complete SRAT simulation took about 38 hours measured from the start of heating prior to acid addition in the SRAT until the time that the SRAT product had cooled to less than $50^{\circ} \mathrm{C}$. 


\subsection{DISCUSSION}

Two SRAT simulations were performed (SB6-10 and SB6-11). They were at 103\% (SB610 ) and $150 \%$ (SB6-11) of the new Koopman minimum stoichiometric acid equation. Both runs met the processing goals of acceptable nitrite destruction and hydrogen generation. The acid window was determined to be sufficiently large to not present an issue for DWPF.

\subsection{SIMULANT AND SRAT PRODUCT CHARACTERIZATION}

The elemental composition of calcined samples of the starting sludge simulant, SB6-D, and two SRAT products are given in Table 2. The three samples were prepared and run on the ICP-AES in duplicate. Values shown are averages of duplicate preparations of each of the three samples.

Table 2. Elemental slurry composition in wt\% after calcining at $1100{ }^{\circ} \mathrm{C}$

\begin{tabular}{|l|c|c|c|}
\hline & SB6-D simulant & SB6-10 product & SB6-11 product \\
\hline $\mathrm{Al}$ & 15.3 & 15.5 & 15.2 \\
\hline $\mathrm{Ba}$ & 0.11 & 0.10 & 0.11 \\
\hline $\mathrm{Ca}$ & 1.01 & 1.15 & 1.13 \\
\hline $\mathrm{Ce}$ & 0.07 & 0.08 & 0.08 \\
\hline $\mathrm{Cr}$ & 0.20 & 0.21 & 0.21 \\
\hline $\mathrm{Cu}$ & 0.08 & 0.08 & 0.05 \\
\hline $\mathrm{Fe}$ & 17.4 & 16.5 & 16.5 \\
\hline $\mathrm{K}$ & 0.07 & 0.11 & 0.07 \\
\hline $\mathrm{La}$ & 0.07 & 0.07 & 0.07 \\
\hline $\mathrm{Mg}$ & 0.50 & 0.51 & 0.51 \\
\hline $\mathrm{Mn}$ & 8.02 & 7.80 & 7.65 \\
\hline $\mathrm{Na}$ & 16.7 & 16.9 & 16.9 \\
\hline $\mathrm{Ni}$ & 2.15 & 2.15 & 2.14 \\
\hline $\mathrm{Pb}$ & 0.01 & $<0.01$ & $<0.01$ \\
\hline $\mathrm{S}$ & 0.24 & 0.28 & 0.27 \\
\hline $\mathrm{Si}$ & 1.13 & 1.23 & 1.24 \\
\hline $\mathrm{Zn}$ & 0.06 & 0.06 & 0.06 \\
\hline $\mathrm{Zr}$ & 0.03 & 0.03 & 0.03 \\
\hline
\end{tabular}

The results were generally consistent within normal random measurement uncertainties. Weight percent total (TS), insoluble (IS), soluble (SS) and calcined (CS) solids values are given in Table 3. 
Table 3. Slurry solids and density data

\begin{tabular}{|l|c|c|c|}
\hline & $\begin{array}{c}\text { SB6-D } \\
\text { simulant }\end{array}$ & $\begin{array}{c}\text { SB6-10 } \\
\text { product }\end{array}$ & $\begin{array}{c}\text { SB6-11 } \\
\text { product }\end{array}$ \\
\hline Supernate density, g/mL & 1.04 & 1.07 & 1.08 \\
\hline Slurry density, g/mL & 1.13 & 1.17 & 1.16 \\
\hline $\mathrm{Wt} \% \mathrm{TS}$ & 16.1 & 23.8 & 22.3 \\
\hline $\mathrm{Wt} \% \mathrm{IS}$ & 10.0 & 13.2 & 11.6 \\
\hline $\mathrm{Wt} \% \mathrm{SS}$ & 6.1 & 10.6 & 10.7 \\
\hline $\mathrm{Wt} \% \mathrm{CS}$ & 12.3 & 14.9 & 13.8 \\
\hline
\end{tabular}

The starting simulant was actually higher in total solids than planned, and it was diluted prior to the SRAT cycle by adding de-ionized water to $88 \%$ of the above total solids value to achieve a total solids content of $14.3 \%$ prior to acid addition. Post-acid addition slurries had to be concentrated by $26-31 \%$ to reach the SRAT product total solids levels above (equivalent to concentrating 8100-8700 gallons to 6000 gallons in DWPF). Concentrating to the equivalent of 6000 gallons at $25 \mathrm{wt} \%$ TS would have required larger initial sludge simulant volumes leading to unrealistic SRAT volumes following acid addition (larger than practical in the lab-scale SRAT).

Selected anion results from IC, titration, and carbon analysis are given in Table 4 for the starting simulant as well as for the two SRAT products.

Table 4. Anion results, $\mathrm{mg}$ anion/kg slurry

\begin{tabular}{|l|c|c|c|}
\hline & $\begin{array}{c}\text { SB6-D } \\
\text { Simulant }\end{array}$ & $\begin{array}{c}\text { SB6-10 } \\
\text { Product }\end{array}$ & $\begin{array}{c}\text { SB6-11 } \\
\text { Product }\end{array}$ \\
\hline Total Inorganic Carbon & 1,651 & n.a. & n.a. \\
\hline Base Equivalents & 0.6328 & n.a. & n.a. \\
\hline Nitrite & 10,800 & $<100$ & $<100$ \\
\hline Nitrate & 7,250 & 18,750 & 20,300 \\
\hline Formate & 0 & 58,500 & 63,600 \\
\hline Chloride & 242 & 494 & 398 \\
\hline Sulfate & 900 & 219 & 170 \\
\hline
\end{tabular}

n.a. - not analyzed (expected to be zero)

$\S$ - moles base/kg slurry instead of $\mathrm{mg} / \mathrm{kg}$ slurry

The SB6-D simulant supernate phase was also analyzed for TIC. The result was 1,426 mg $\mathrm{TIC} / \mathrm{L}$ supernate, or $1,235 \mathrm{mg} \mathrm{TIC} / \mathrm{kg}$ slurry. About $75 \%$ of the TIC was in the supernate, while $25 \%$ was in the sludge insoluble solids. Mercury and noble metals were added to both SRAT simulations at a single set of target values, Table 5 . 
Table 5. Mercury and noble metal targets, wt\% in total solids

\begin{tabular}{|l|c|c|c|c|c|}
\hline $\mathrm{Wt} \%$ in TS & $\mathrm{Ag}$ & $\mathrm{Pd}$ & $\mathrm{Rh}$ & $\mathrm{Ru}$ & $\mathrm{Hg}$ \\
\hline Phase II & 0.0135 & 0.0054 & 0.0200 & 0.0943 & 3.50 \\
\hline Phase I & 0.0002 & 0.0158 & 0.0202 & 0.0980 & 1.50 \\
\hline
\end{tabular}

The values for $\mathrm{Rh}, \mathrm{Ru}$, and $\mathrm{Hg}$ were relatively high compared to previous sludge batches.

\subsection{OFF-GAS DATA}

Off-gas data from the two simulations were evaluated as a function of time measured from the start of nitric acid (or essentially at times of equivalent moles of acid added). The data for carbon dioxide are shown in Figure 1.

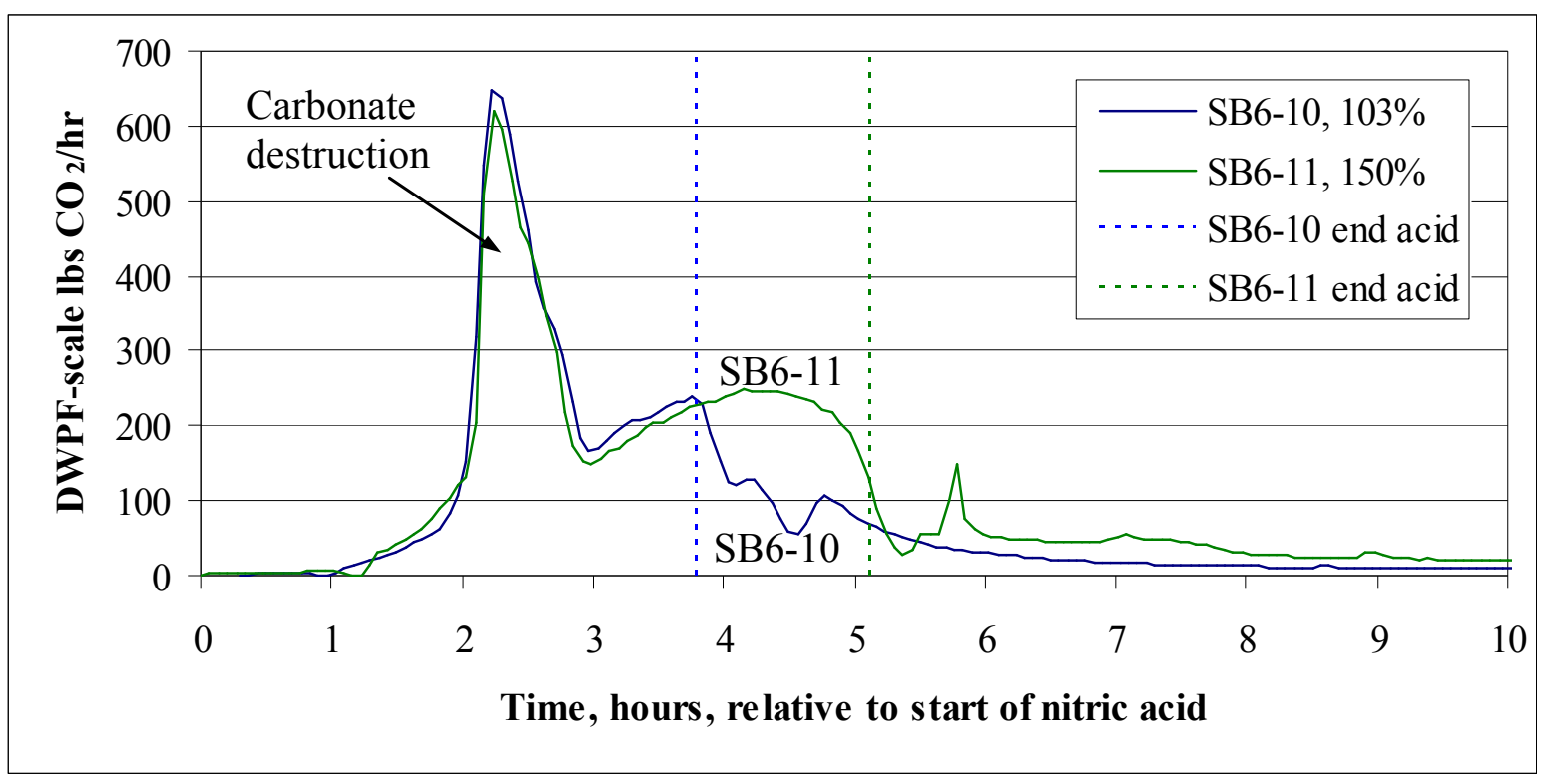

Figure 1. $\mathrm{CO}_{2}$ production in the early SRAT cycle

The dashed vertical lines mark the end of formic acid addition in the two runs. The conversion of carbonate around 2-3 hours after the start of nitric acid addition was virtually identical in the two simulations based on the $\mathrm{CO}_{2}$ evolution profiles. The initial phase of nitrite destruction (3-4 hours after starting acid) was also nearly identical. The high acid run, however, produced considerably more $\mathrm{CO}_{2}$ than the low acid run during the period between the two different ends of formic acid addition (3.8-5.1 hours). This difference indicates greater catalytic activity in SB6-11 which was expected to produce more $\mathrm{N}_{2} \mathrm{O}$ and lower nitrite-to-nitrate conversion. The corresponding $\mathrm{N}_{2} \mathrm{O}$ data are given in Figure 2. 
SRNL-STI-2010-00041, REV. 0

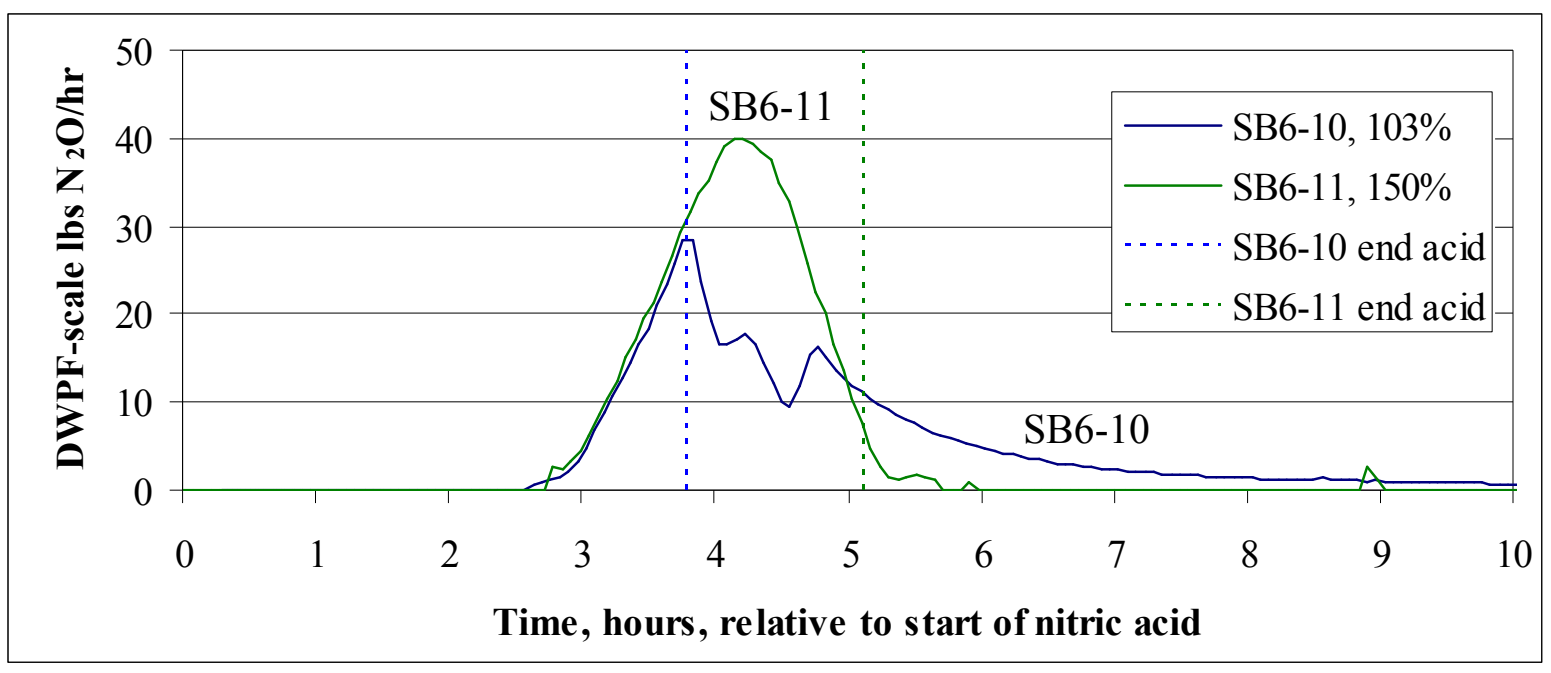

Figure 2. $\mathrm{N}_{2} \mathrm{O}$ production in the early SRAT cycle

The $\mathrm{N}_{2} \mathrm{O}$ production rate was apparently controlled by the rate of acid addition initially (linear increase in rate of production as acid was added at a constant rate, or $\mathrm{d}\left[\mathrm{N}_{2} \mathrm{O}\right] / \mathrm{dt}=\mathrm{a}^{*} \mathrm{t}$ ), rather than by either the nitrite ion concentration or acid concentration $(\mathrm{pH})$. In SB6-10, the end of acid addition (dashed vertical blue line) resulted in an immediate reduction in production rate. In SB6-11, however, the concentration of nitrite fell sufficiently before the end of formic acid addition that the rate of $\mathrm{N}_{2} \mathrm{O}$ formation began to fall due to a shortage of nitrite before acid addition was completed (at about 4.1 hours into acid addition).

Nitrite concentration was checked immediately after formic acid addition. The concentration was 5,500 mg/kg in SB6-10 and less than $100 \mathrm{mg} / \mathrm{kg}$ in SB6-11. At this point, there was a higher nitrate ion concentration in SB6-11 (17,000 mg/kg) than in SB6-10 (12,000 mg/kg). This difference could be attributed to the higher nitric acid addition in SB6-11 which was equivalent to 4,900 additional $\mathrm{mg}$ nitrate/kg compared to SB6-10. In SB6-11, however, about 5\% more nitrate was accounted for after acid addition than was added with the sludge or in the trim chemicals and during nitric acid addition. Therefore, weak evidence (due to analytical uncertainties) exists for some nitrite-to-nitrate conversion prior to the end of acid addition.

Figure 2 shows that more $\mathrm{N}_{2} \mathrm{O}$ was produced in SB6-11 than SB6-10 (21\% more). The greater extent of catalyzed reactions in SB6-11, initially inferred from the $\mathrm{CO}_{2}$ data, was supported by the $\mathrm{N}_{2} \mathrm{O}$ data. Overall nitrite-to-nitrate conversion was 9\% in SB6-10 and $-15 \%$ in SB6-11. This difference was also consistent with greater catalytic destruction of nitrite using formic acid in SB6-11. The negative nitrite-to-nitrate conversion value for SB6-11 and the small positive value for SB6-10 suggest that catalytic formation of ammonium ion from nitrate was occurring in addition to nitrite destruction. (Nitrite and ammonium do not coexist for long in acidic aqueous systems at elevated temperatures, since they react together to produce nitrogen gas.)

General details concerning SRAT product composition are summarized in Section 4.5. Specific SRAT product results directly relevant to the off-gas data are discussed as 
appropriate in the text below. About $24 \%$ of the nitrate present after acid addition in SB6-11 did not survive the remainder of the SRAT cycle. (This includes sludge and trim chemical nitrate, added nitric acid, and some portion of the nitrite converted to nitrate during nitrite destruction.) A concentration of $1,390 \mathrm{mg}$ ammonium ion/ $\mathrm{kg}$ slurry was found in the SRAT product. An additional 3,240 $\mathrm{mg}$ ammonium/L was found in the collected condensate from the lab-scale Formic Acid Vent Condenser (FAVC). The SB6-10 FAVC condensate contained only $7 \mathrm{mg}$ ammonium ion/L. The lab-scale FAVC condensate is a cumulative sample over the entire SRAT cycle that is generally collected at the end of the SRAT. The mass of FAVC condensate is typically only about $1 \%-3 \%$ of the SRAT product slurry mass. The lab-scale FAVC condensate typically has a concentration of over a hundred thousand ppm nitrate (as nitric acid) from the absorption of $\mathrm{NO}_{2}$ into the cold condensing water droplets, and it is very acidic. Ammonium formation is discussed further in Section 4.4.

The complete SRAT carbon dioxide generation profiles for the two simulations are shown in Figure 3 plotted relative to the time of the end of formic acid addition.

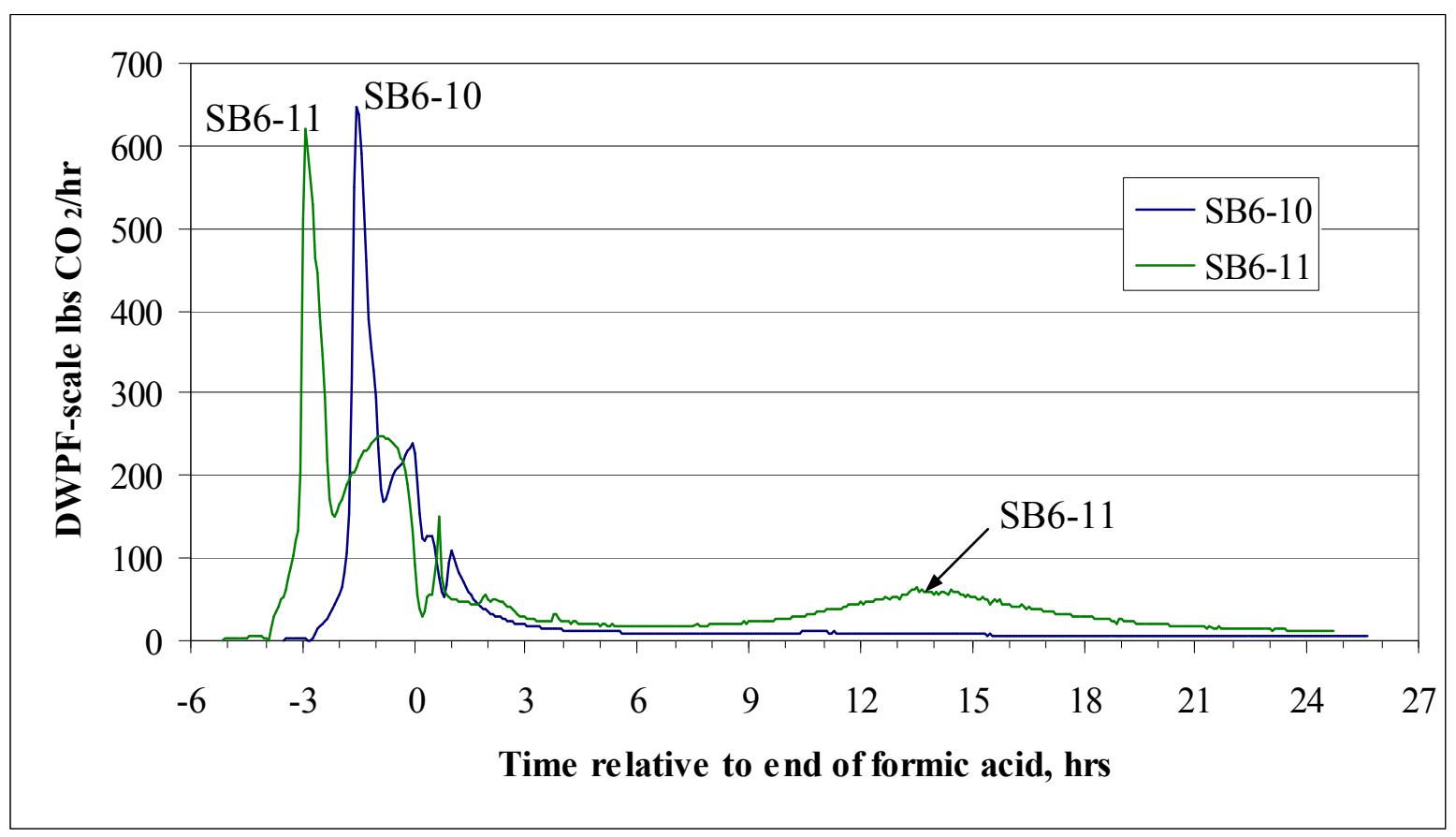

Figure 3. Complete $\mathrm{CO}_{2}$ profiles for the two SRAT cycles

A period of enhanced $\mathrm{CO}_{2}$ production occurred during reflux centered at about 14 hours after the end of formic acid addition in SB6-11. This period may also be associated with the conversion of nitrate to ammonium (catalytically adsorbed nitrate is believed to be reduced to nitrite ion, then to $\mathrm{NO}$, and finally hydrogenated to ammonium in a series of reactions). The overall reaction is given by:

$$
5 \mathrm{HCO}_{2} \mathrm{H}+\mathrm{NO}_{3}^{-} \rightarrow \mathrm{NH}_{3}+\mathrm{HCO}_{2}^{-}+4 \mathrm{CO}_{2}+3 \mathrm{H}_{2} \mathrm{O}
$$


Although 41\% more formic acid was added to SB6-11 than SB6-10, SB6-11 had just 63,600 $\mathrm{mg}$ formate $/ \mathrm{kg}$ slurry $(153.8 \mathrm{~g})$ in the SRAT product compared to $58,500 \mathrm{mg} / \mathrm{kg}(129.6 \mathrm{~g})$ in SB6-10. A gain of only $18 \%$ in SRAT product formate resulted from a $41 \%$ increase in formic acid added. The formate loss was 31\% in SB6-11 compared to 17\% in SB6-10. Since the formate loss and $\mathrm{CO}_{2}$ produced in SB6-11 are in agreement, it may be that the period of $\mathrm{CO}_{2}$ production between 6 and 21 hours after formic acid addition was associated with ammonia formation as well.

The combination of $47 \%$ higher acid stoichiometry and high noble metal concentrations led to significant hydrogen generation in SB6-11 in spite of the high initial mercury concentration, Figure 4.

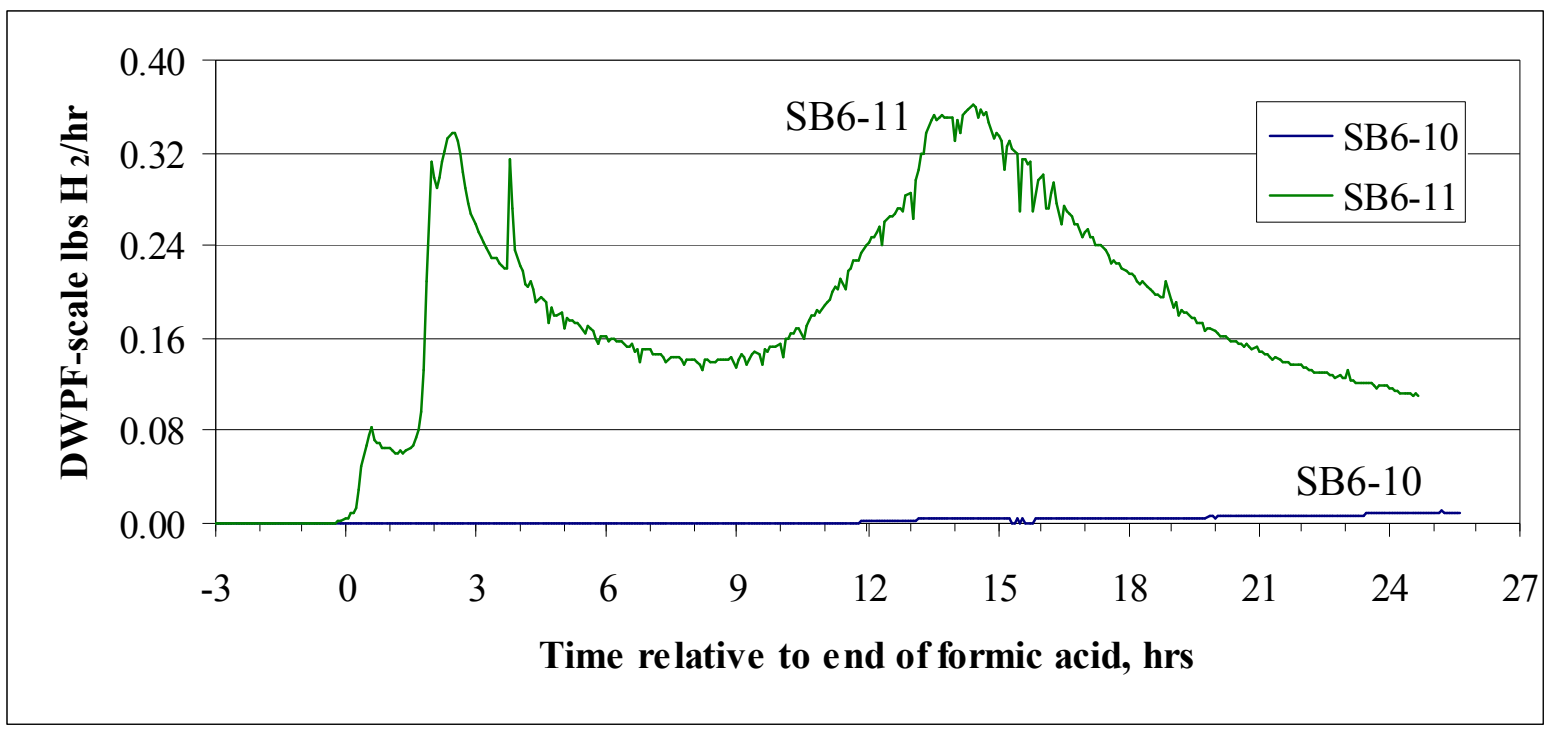

Figure 4. SRAT cycle hydrogen generation rate profiles

SB6-11 exceeded half of the scaled DWPF SRAT cycle limit of $0.65 \mathrm{lbs}$ hydrogen/hr at two distinctly separate times during the SRAT cycle, but stayed below $60 \%$ of the limit. Hydrogen generation was initiated near the end of nitrite destruction in both runs; however nitrite destruction occurred near the end of formic acid addition in SB6-11, while $\mathrm{GC}_{2} \mathrm{O}$ data indicate that it occurred at about 12 hours after the end of formic acid addition in SB610. The SB6-10 data indicate that a small quantity of excess acid was present at $103 \%$ of the Koopman minimum acid equation, since nitrite went to less than $100 \mathrm{mg} / \mathrm{kg}$, and non-zero hydrogen production (0.010 lbs $\mathrm{H}_{2} / \mathrm{hr}$ at DWPF scale) was observed.

The second period of hydrogen generation in SB6-11 (from 10-24 hours after acid) coincides with the period of renewed $\mathrm{CO}_{2}$ generation in Figure 3. Based on work in the catalytic hydrogen program, this period is probably dominated by $\mathrm{Ru}$ catalyzed hydrogen generation rather than Rh catalyzed hydrogen generation. ${ }^{9}$ It is noteworthy that the peak at about 15 hours was at a slightly higher hydrogen generation rate than the peak at about two hours (presumed to be the $\mathrm{Rh}$ peak). It has been far more common for the $\mathrm{Rh}$ catalyzed peak to be at a higher hydrogen generation rate than the Ru catalyzed peak. This may be a result of the 
high mercury concentration which catalyzes nitrite destruction and thereby shortens the period that $\mathrm{Rh}$ (as a nitro $\mathrm{Rh}$ complex) is at its maximum catalytic activity for hydrogen generation.

A second, smaller period of $\mathrm{N}_{2} \mathrm{O}$ generation was observed during reflux in SB6-11. This is shown in Figure 5.

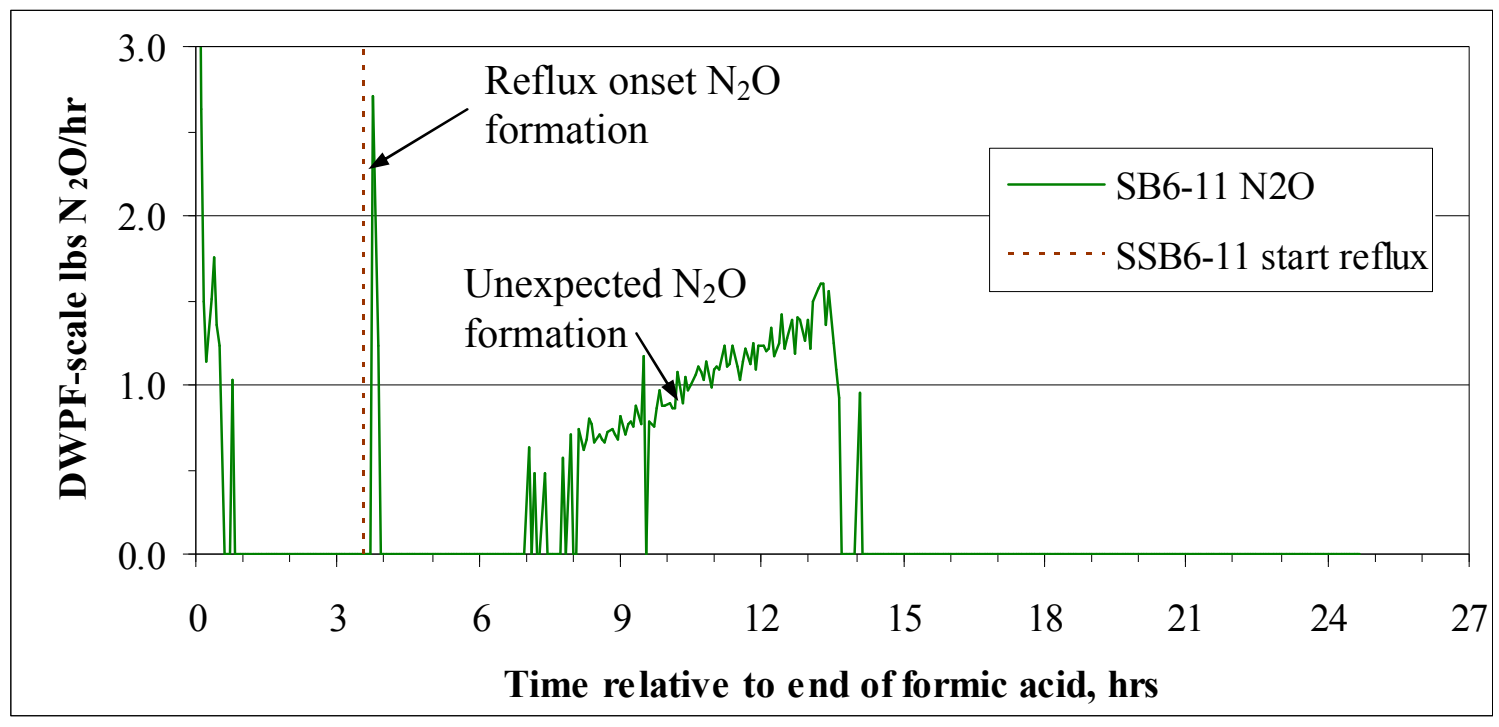

Figure 5. $\mathrm{N}_{2} \mathrm{O}$ and $\mathrm{CO}_{2}$ generation during boiling in $\mathrm{SB6}-11$

A small burst of $\mathrm{N}_{2} \mathrm{O}$ following the start of reflux is not uncommon (at 3.8 hours). $\mathrm{NO}_{2}$ has been absorbed into the SRAT condenser condensate going into the MWWT during nitrite destruction in the SRAT where it has disproportionated into nitrite and nitrate ions. When reflux is initiated, the surviving nitrite is refluxed into the SRAT and destroyed producing some $\mathrm{N}_{2} \mathrm{O}$. In SB6-11, however, there was a subsequent six hour period during which additional $\mathrm{N}_{2} \mathrm{O}$ was produced (generally no $\mathrm{N}_{2} \mathrm{O}$ is seen during this period in a SRAT cycle with this much excess acid). This was occurring as the hydrogen production rate decreased between the $\mathrm{Rh}$ and $\mathrm{Ru}$ catalyzed peaks.

Some of the newer features in the off-gas data, such as the second peaks in $\mathrm{CO}_{2}$ and $\mathrm{H}_{2}$ generation, occurred after 10-12 hours of boiling. They may be due to the presence of high mercury concentrations in the starting feed for example, or they may simply reflect the fact that most SRAT simulations were stopped after twelve hours of reflux before these features would have been seen.

\subsection{MERCURY}

Special attention was given to mercury removal once the high initial concentration of SB6 was identified. The mercury concentration of the starting feed was expected to require additional boiling time to reduce the $\mathrm{Hg}$ concentration to below $0.45 \mathrm{wt} \%$ in the SRAT product total solids (DWPF specification). SB6-10 and 11 had about four hours of 
dewatering combined with 21 hours of reflux, or 25 total hours of steam stripping at the labscale equivalent to 5,000 lbs steam/hr in DWPF. At low agitator speeds during acid addition, a film of colloidal mercury droplets (presumably) could be observed in the SRAT floating on the slurry. Increasing mixing speed drew this material back down into the slurry. Foaming was not a problem using the DWPF SRAT antifoam protocols. (The old Dow Corning antifoam, however, was particularly susceptible to foaming when colloidal mercury was present in testing with SB1B simulant. ${ }^{10}$ )

Following dewatering, the initial mercury charged to SB6-10 was equivalent to $6,790 \mathrm{mg}$ $\mathrm{Hg} / \mathrm{kg}$ slurry assuming no removal. The equivalent value for SB6-11 was $6,130 \mathrm{mg} / \mathrm{kg}$. Because the acids are very concentrated solutions, and since more acid (more nitrate and formate) was added to SB6-11, it increased in total solids mass by more than it increased in water mass. Consequently, it required a smaller mass of water to be removed than SB6-10 to reach a similar $w t \%$ total solids endpoint after acid addition. More acid added plus less dewatering led to a larger remaining slurry mass in the vessel. Starting materials, including $\mathrm{Hg}$, were more dilute in SB6-11 slurry during reflux because they were diluted in a higher total mass system than SB6-10. Samples of SRAT slurry were pulled and digested using the aqua regia method at ACTL. Digested samples were run by both ICP-AES and CV-AA.

The ICP-AES results are given in Figure 6 plotted versus the reflux time. The CV-AA results were similar but somewhat noisier and are shown as diamonds. Reflux started about 4.5 hours after formic acid addition in SB6-10 and 3.5 hours after formic acid in SB6-11. The first five points in each series represent single samples, while the sixth point is an average of results from two independent samples of the SRAT product slurry.

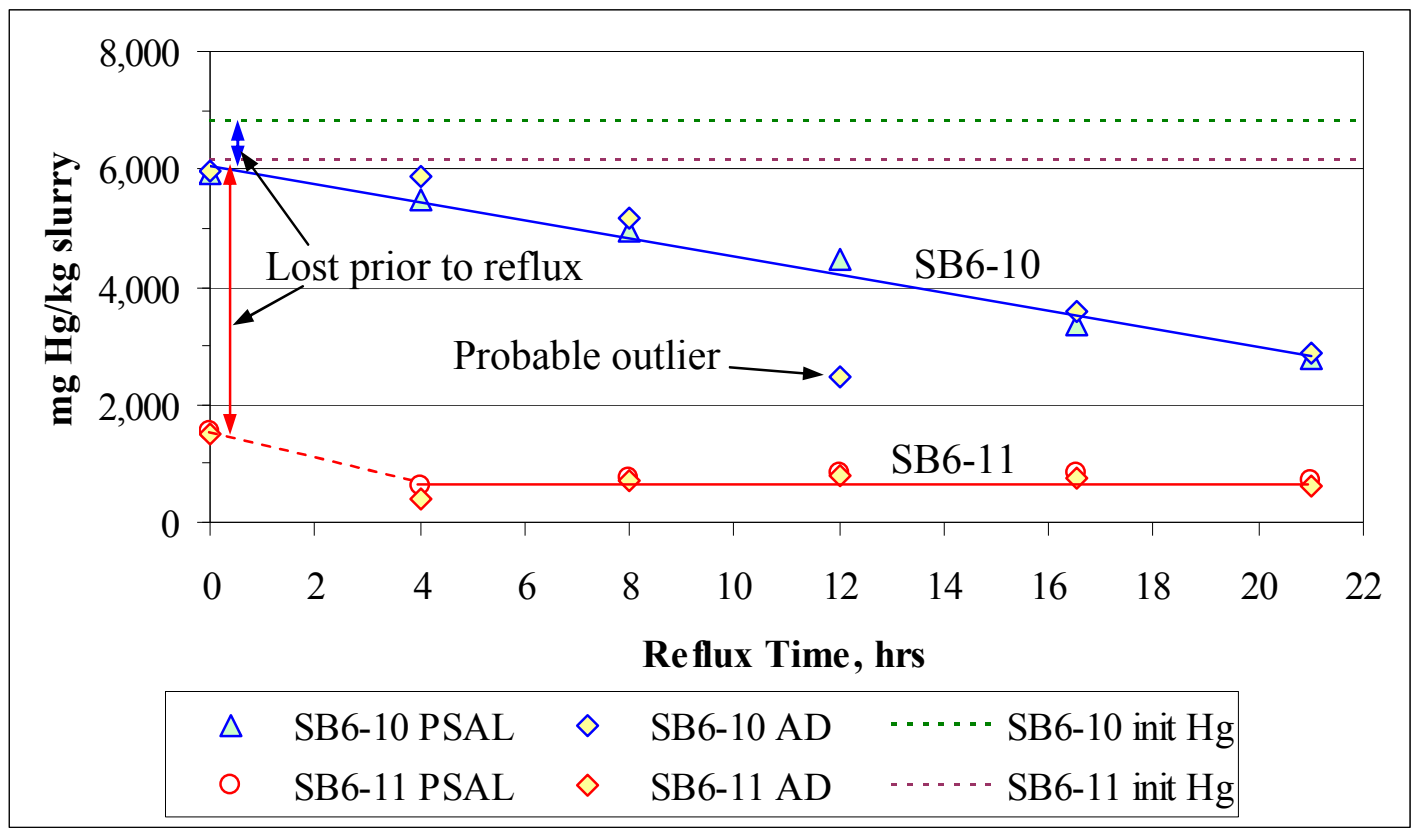

Figure 6. Sample results for mercury removal 
The data show several things. First, the data appear to provide internally consistent sets for both runs (no signs of major outliers or non-representative sampling except for the AD point at 12 hours in SB6-10). Second, significant mercury removal from the bulk slurry had occurred during acid addition and dewatering, that is prior to reflux. The slurry mercury concentration was significantly below the maximum value in the case of SB6-11 (based on mercury added and by material balance) by the start of reflux, and somewhat below in the case of SB6-10. Third, the rate of removal was nearly linear in SB6-10. Fourth, SB6-11 apparently reached a condition after just four hours of reflux where further stripping of mercury did not occur.

Each run had $15.84 \mathrm{~g}$ of the element mercury added to it in the form of HgO. SRAT product sample data and mass indicate removal of $9.3 \mathrm{~g}$ in SB6-10 and of $14.1 \mathrm{~g}$ in SB6-11 (59\% and $89 \%$ ). Removal is not presumed to necessarily be equivalent to stripping. The $\mathrm{Hg}$ concentrations in the SRAT product slurry total solids were $1.16 \mathrm{wt} \%$ and $0.31 \mathrm{wt} \%$ for SB610 and 11 respectively. To meet the DWPF target of $0.45 \mathrm{wt} \% \mathrm{Hg}$ in the SRAT product total solids, SB6-10 needed more stripping time than the 25 hours given. SB6-11 apparently required significantly less time assuming the missing mercury has been stripped successfully. Generally comparable mercury sample results were obtained on the first pair of tests with SB6 qualification simulant (at 103\% and 150\% acid, reported separately) ${ }^{11}$, though there were quantitative differences in removal rates. Data from acid window studies for SB5 seem to confirm that the mercury content of the SRAT product slurry decreases with increasing acid stoichiometry. ${ }^{12}$ Mercury removal in the four recent sludge matrix study SRAT simulations at low acid stoichiometry generally failed to meet the SRAT product specification. ${ }^{13}$ Potential explanations for these observations are being evaluated.

The contents of the MWWT were checked for mercury. An elemental mass of $7.5 \mathrm{~g}$ of $\mathrm{Hg}$ was found in the SB6-10 MWWT versus a projected $9.3 \mathrm{~g}$ removed from the SRAT slurry. Lesser amounts of $\mathrm{Hg}$ could be seen adhering to the walls of the SRAT condenser, condenser drain to the MWWT, and inside the MWWT. The large mass removed was relatively clean and shiny and had fully coalesced into single large homogeneous droplet.

Conversely, only $3.4 \mathrm{~g}$ of elemental $\mathrm{Hg}$ were recovered from the MWWT of SB6-11 compared to a projected $14.1 \mathrm{~g} \mathrm{Hg}$ stripped from the SRAT slurry based on the sample results. Lesser amounts were visible on the equipment though not appreciably more or less than in SB6-10. The small mass of recovered elemental $\mathrm{Hg}$ may be correlated to the short period of time that mercury appeared to be actively stripping. The elemental mercury removed from the MWWT was ragged in appearance and had not coalesced into a single large droplet. There was a dark material adhering to the surface of the mercury that seemed to be preventing some of the droplets from coalescing. Agitating and tapping the sample bottle did not overcome the surface barrier to coalescence. (Similar observations on the nature of the recovered elemental mercury phase were made in the low-high acid tests with SB6 qualification simulant, i.e. that the mercury in the high acid run was dirtier than the low acid run; but recovered mass variations were somewhat different). ${ }^{11}$ The final location of a majority of the mercury in SB6-11 was not determined. 
The SB6-11 SRAT stainless steel agitator blades and shaft were significantly discolored after cleaning the sludge off (SB6-10 parts were not). In SB6-11, roughly 10.7 of the $15.8 \mathrm{~g}$ of mercury added were not accounted for in the SRAT product slurry or MWWT elemental Hg phase (material balance closure of only $32 \%$ ). Neither run had visible elemental mercury in the SRAT dewatering condensate. Both SRAT vessels had only a small amount of visible $\mathrm{Hg}$ after removing the bulk slurry (but perhaps not all segregated mercury is readily visible). An increased sampling plan was implemented for the SB6 qualification simulant studies (starting sampling earlier, checking condensates), and the plan will be modified as needed prior to starting the Phase III SB6 simulant flowsheet studies in an attempt to determine where the $\mathrm{Hg}$ is going.

\subsection{AMMONIUM ION FORMATION}

The two SB6-D simulant runs were initially checked for the presence of detectable ammonium ion in the SRAT cycle FAVC condensate. This sample was selected to test for ammonium ion formation because it is aqueous and does not have any interferences from sodium, potassium, etc. when performing cation chromatography. SB6-11 FAVC condensate had 3,240 mg ammonium/L versus just $7 \mathrm{mg} / \mathrm{L}$ in SB6-10 FAVC condensate. Four FAVC condensates from the recent sludge matrix study low acid stoichiometry runs had all been analyzed at 5-10 $\mathrm{mg} / \mathrm{L}$ as well. ${ }^{13}$

SB6-11 SRAT product was submitted for ammonium ion analysis following review of the FAVC results. A value of $1,390 \mathrm{mg}$ ammonium ion/L was reported. An approximate nitrogen balance was performed (values for nitrate in the condensates were not available). Nitrogen "in" was at $1.5 \pm 0.1$ moles from nitrate, nitrite, and nitric acid. Nitrogen "out" was at $1.4 \pm 0.2$ moles from nitrate in the SRAT product, $\mathrm{N}_{2} \mathrm{O}$, and $\mathrm{NO}_{\mathrm{x}}$ (not counting ammonium). Uncertainties were derived assuming $\pm 10 \%$ for nitrite, nitrate, and ammonium by IC and for off-gas $\mathrm{N}_{2} \mathrm{O}$ by GC, and $\pm 20 \%$ for $\mathrm{NO}_{\mathrm{x}}$ which is based on assumptions related to oxygen consumption and GC column historical performance. The combined ammonium ion in the SB6-11 SRAT product and FAVC condensate was determined to be $0.2 \pm 0.02$ moles. The nitrogen material balance is not sufficiently accurate to quantify the total potential ammonium ion formation due to the cumulative analytical uncertainties (of order 0.3 moles), but it does not contradict the ammonium ion sample data.

The nitrogen species mass balance also suggests that no major quantities of ammonia gas escaped in the off-gas. The lab-scale SRAT condenser off-gas passes directly into a Nafion dryer followed by a chilled condenser $\left(4^{\circ} \mathrm{C}\right)$. There is no ammonia scrubber, since the apparatus was not designed to study downstream DWPF unit operations. The lab-scale chilled condenser is significantly oversized compared to the DWPF FAVC, however, which may serve to enhance ammonia absorption efficiency into the chilled condensate present inside, that is, make the lab-scale FAVC accomplish much the same thing as the DWPF ammonia scrubber.

Another impacted calculation was the nitrite-to-nitrate conversion percentage (typically 10$25 \%$ as moles nitrite converted to moles nitrate). The result for SB6-11 was $-15 \%$, supporting a net loss of nitrate in addition to the destruction of nitrite. The result for SB6-10 
was $+9 \%$. Samples taken immediately after acid addition, however, indicated nitrate gains in both runs. The preliminary conclusions are that:

- ammonia/ammonium ion was generated in significant quantities

- net nitrate loss was observed overall in the SRAT, even though a nitrate increase was initially indicated following formic acid addition

- the amount of ammonia generated was strongly dependent on acid stoichiometry

- $95 \%$ of the ammonia was still in the SRAT product versus just $5 \%$ in the condensate in SB6-11

- a nitrate loss in excess of $20 \%$ may have occurred during ammonia formation

The ammonium ion in the SRAT product could conceivably survive until entering the DWPF melter and decompose into the melter off-gas releasing hydrogen atoms. The nitrogen valence of ammonia versus nitrate is -3 versus +5 , so ammonia is a potential reductant in the same sense that nitrate is an oxidizer. Further tests for ammonium ion were added to the SB6 simulant tests supporting the Shielded Cells qualification test for SB6-Tank 51. Preliminary qualification simulant results support the first three preliminary conclusions above, but a higher percentage of ammonia was collected in the FAVC (20-35\%) relative to the SRAT product $(65-80 \%)$.

It is hypothesized that mercury catalyzed the attack of excess formic acid on nitrate ions to produce the ammonium ions. Alternatively, mercury may have promoted catalysis by the noble metals (previous SRAT tests at very high acid and high noble metals without mercury produced much less ammonium ${ }^{14}$ ). Another hypothesis is that mercury is promoting ammonium ion formation indirectly by extending the boiling time relative to prior sludge batches. Initial evaluations of the behavior of formate destruction (graph of $2 * \mathrm{O}_{2}+\mathrm{CO}_{2}$ ), however, suggest that there is no unusual formate loss focused in the extra SRAT time, Figure 7. 
SRNL-STI-2010-00041, REV. 0

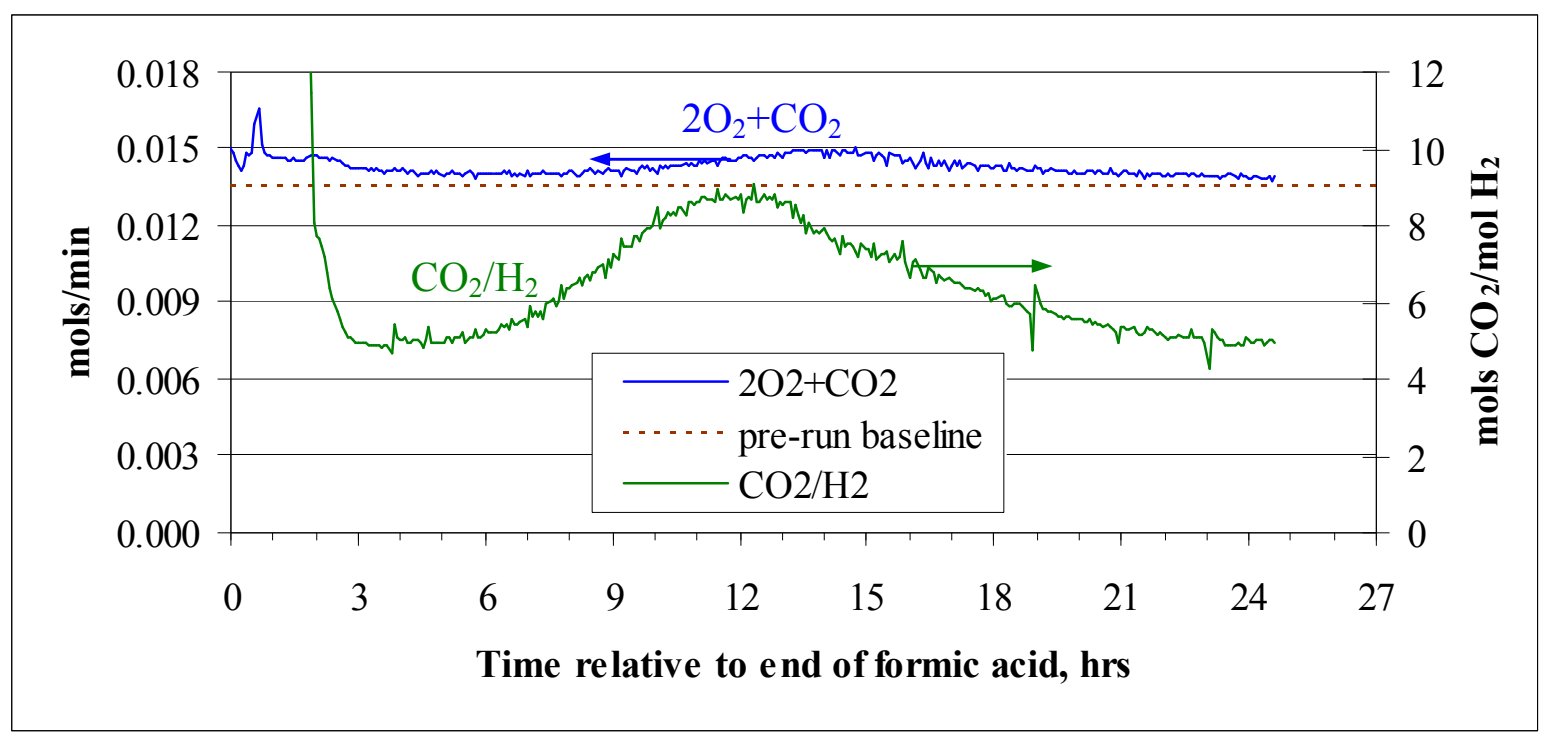

Figure 7. Signs of non-oxidative formate loss during SB6-11

The periods from 0 to 4 hours and 9-18 hours after the end of formic acid addition show the most formate loss not associated with oxidation reactions (the regions where the blue curve for $2 \mathrm{O}_{2}+\mathrm{CO}_{2}$ is the most above the pre-run baseline value of $0.0135 \mathrm{mols} / \mathrm{min}$ ). The deviations are small and there is also some drift in the calibration of the two gases with time. The regions of deviation somewhat align with the hydrogen evolution data, Figure 4, but the magnitude of the excess $\mathrm{CO}_{2}$ production significantly exceeds the molar production rate of hydrogen. There is a period from 6 to 18 hours after acid addition where the production of $\mathrm{CO}_{2}$ relative to $\mathrm{H}_{2}$ is enhanced, reaching nearly nine to one versus as low as five to one at other times. This is one likely period for ammonia formation per the reaction below:

$$
5 \mathrm{HCO}_{2} \mathrm{H}+\mathrm{NO}_{3}^{-} \rightarrow \mathrm{NH}_{3}+\mathrm{HCO}_{2}^{-}+4 \mathrm{CO}_{2}+3 \mathrm{H}_{2} \mathrm{O}
$$

The data in Figure 7 could be interpreted to indicate that the reaction producing ammonia was peaking about 12 hours after acid addition and had slowed considerably before the SRAT cycle was terminated. That would place the peak ammonia generation period within the reflux portion of many prior SRAT simulations that have run to 14-16 hours past the end of formic acid addition (2-4 hours dewatering plus 12 hours reflux). These earlier SRAT runs did not generally have negative nitrite-to-nitrate conversions apparently associated with ammonia formation just as they did not have unusually high mercury concentrations. An exception is the recent SB5 flowsheet testing. ${ }^{15}$ Negative nitrite-to-nitrate conversions were seen in some of the higher acid runs. The SB5 tests had mercury concentrations ranging from $2.37-2.72 \mathrm{wt} \%$ in the starting sludge solids. The SB5 Hg levels were higher than in the past although lower than the current SB6 testing.

Another likely period for ammonium formation is immediately following nitrite destruction. It was noted that the nitrite-to-nitrate conversion as measured immediately after acid addition in the high acid run was small but positive. The $7-8 \%$ net nitrite-to-nitrate conversion, however, was lower than normal, and this could indicate that ammonium ion formation had 
already started during the latter stages of acid addition. Sampling the SRAT as a function of time appears to be necessary to better define the period when ammonium is being produced.

\subsection{SUPPLEMENTAL DATA}

The tables below summarize some of the analyses that were briefly mentioned in the discussions above related to specific reactions such as nitrite-to-nitrate conversion. Anion data were obtained on the starting sludge, the two SRAT products, two caustic-quenched samples after acid addition and two caustic-quenched samples 30 minutes prior to turning off mantle power to end the SRAT cycle. These data are given in Table 4.

Table 6. Anion results, mg anion/kg slurry

\begin{tabular}{|l|c|c|c|c|c|c|c|}
\hline & $\begin{array}{c}\text { SB6-D } \\
\text { Simulant }\end{array}$ & $\begin{array}{c}\text { SB6-10 } \\
\text { After } \\
\text { Acid }\end{array}$ & $\begin{array}{c}\text { SB6-10 } \\
\text { near end }\end{array}$ & $\begin{array}{c}\text { SB6-10 } \\
\text { Product }\end{array}$ & $\begin{array}{c}\text { SB6-11 } \\
\text { After } \\
\text { Acid }\end{array}$ & $\begin{array}{c}\text { SBS6-11 } \\
\text { near end }\end{array}$ & $\begin{array}{c}\text { SB6-11 } \\
\text { Product }\end{array}$ \\
\hline Nitrite & 10,800 & 5,780 & $<100$ & $<100$ & $<100$ & $<100$ & $<100$ \\
\hline Nitrate & 7,250 & 12,550 & 17,800 & 18,750 & 18,150 & 21,200 & 20,300 \\
\hline Formate & 0 & 45,000 & 58,300 & 58,500 & 61,400 & 64,800 & 63,600 \\
\hline Chloride & 242 & 190 & 480 & 494 & 130 & 400 & 398 \\
\hline Sulfate & 900 & $<100$ & 280 & 219 & $<100$ & 200 & 170 \\
\hline
\end{tabular}

Reasonable agreement was obtained between the near end of SRAT and SRAT product results for nitrate and formate. (Caustic quenched samples are mainly to track nitrite, nitrate, and formate at moments in the process by shutting down acid driven reactions.) Data indicate that sulfate was only partially soluble after acid addition. ICP-AES data for sulfur indicate that only approximately $5-20 \%$ of the total sulfur was present as soluble sulfate in the SRAT products and caustic quenched samples (the only source of sulfur in the starting simulant was sodium sulfate). There were about $150 \mathrm{mg} / \mathrm{kg} \mathrm{Cl}$ from the addition of $\mathrm{RuCl}_{3}$ in the six results other than for SB6-D simulant. Chloride did not appear to be totally soluble near the end of acid addition in the caustic-quenched after acid samples of either run.

The samples after acid addition indicate that nitrate was at $109 \%$ of the added nitrate in SB610 and was at $105 \%$ of the added nitrate in SB6-11, in other words nitrite-to-nitrate conversion had occurred during acid addition. In the case of SB6-10, nitrite destruction was only $37 \%$ complete at the end of acid addition. Destruction of the remaining $63 \%$, however, did not lead a further gain in nitrate within the uncertainty of the analytical measurements and material balance calculations. This may imply some ammonium formation in the low acid run. In the case of SB6-11, nitrite destruction was already complete at the end of acid addition, and further processing led to a net loss in nitrate (presumably the majority of this loss went to ammonium plus a small amount of $\mathrm{N}_{2} \mathrm{O}$ ) as discussed in Section 4.4.

Cation dissolution data were obtained after acid addition and in the SRAT product. These results were obtained by analyzing supernate samples for elemental concentrations in $\mathrm{mg} / \mathrm{L}$ supernate, combining these results with slurry data for the elements in $\mathrm{mg} / \mathrm{kg}$, and using supernate density and wt. \% insoluble solids to convert the supernate measurements to $\mathrm{mg} / \mathrm{kg}$ 
slurry. The percentage of the element in the supernate was then obtained by taking the ratio of the two quantities on a $\mathrm{mg} / \mathrm{kg}$ slurry basis.

Table 7. Percentages of elements in supernate phase

\begin{tabular}{|l|c|c|c|c|}
\hline & $\begin{array}{c}\text { SB6-10 } \\
\text { After acid }\end{array}$ & $\begin{array}{c}\text { SB6-10 } \\
\text { Product }\end{array}$ & $\begin{array}{c}\text { SB6-11 } \\
\text { After acid }\end{array}$ & $\begin{array}{c}\text { SB6-11 } \\
\text { Product }\end{array}$ \\
\hline $\mathrm{Ca}$ & 66 & 57 & 73 & 92 \\
\hline $\mathrm{Cu}$ & 10 & 0.1 & 61 & 0.8 \\
\hline $\mathrm{Mg}$ & 36 & 34 & 52 & 77 \\
\hline $\mathrm{Mn}$ & 41 & 35 & 69 & 68 \\
\hline $\mathrm{Ni}$ & 18 & $<0.01$ & 40 & 0.15 \\
\hline $\mathrm{Rh}$ & 52 & 2.2 & 14 & 2.0 \\
\hline $\mathrm{Ru}$ & 13 & $<1$ & 19 & 1.4 \\
\hline $\mathrm{S}$ & 46 & 13 & 55 & 56 \\
\hline $\mathrm{Zn}$ & 5 & $<0.2$ & 20 & $<0.2$ \\
\hline
\end{tabular}

The SB6-10 manganese data are qualitatively consistent with assuming approximately 50\% reductive dissolution in the Koopman minimum acid equation. The SB6-10 calcium data are qualitatively consistent with assuming approximately $75 \%$ solubility as acid reactive compounds (carbonates and hydroxides). The SB6-10 magnesium data indicate that the 75\% dissolution of $\mathrm{Mg}(\mathrm{OH})_{2}$ assumed in the Koopman minimum acid equation may be too high. Alternatively, the $\mathrm{Mg}$ may be dissolving and reprecipitating (reprecipitation of $\mathrm{Mg}$ was not indicated in the extensive bead-frit SRAT processing data but that was a different composition system). Dissolution data were not obtained for SB6-10 and -11 during the period when $\mathrm{Mg}$ dissolution occurs (near and just below a $\mathrm{pH}$ of seven).

The two key noble metals, Rh and Ru, behaved as in past runs where they were more soluble early in the SRAT and less soluble by the end of the SRAT. Sodium and potassium were essentially $100 \%$ in solution while other elements not shown were essentially $100 \%$ insoluble. The SB6-10 sulfur data and sulfate data show opposite trends. However the higher values for supernate sulfur and sulfate in the SRAT product are essentially identical. Caustic quenching the SB6-10 post acid addition slurry sample apparently caused a significant fraction of the sulfate to precipitate (even though the sulfate in the caustic simulant feed was soluble). The data are insufficient to select between the various alternative hypotheses including the possibility that there is an outlier in the sample data.

Rheological data were not obtained during Phase II, since the expected composition for SB6 changed during the preparation of SB6-D simulant. Rheological data will be obtained from Phase III flowsheet studies instead. The $\mathrm{pH}$ data for the two runs is given in Figure 8. 
SRNL-STI-2010-00041, REV. 0

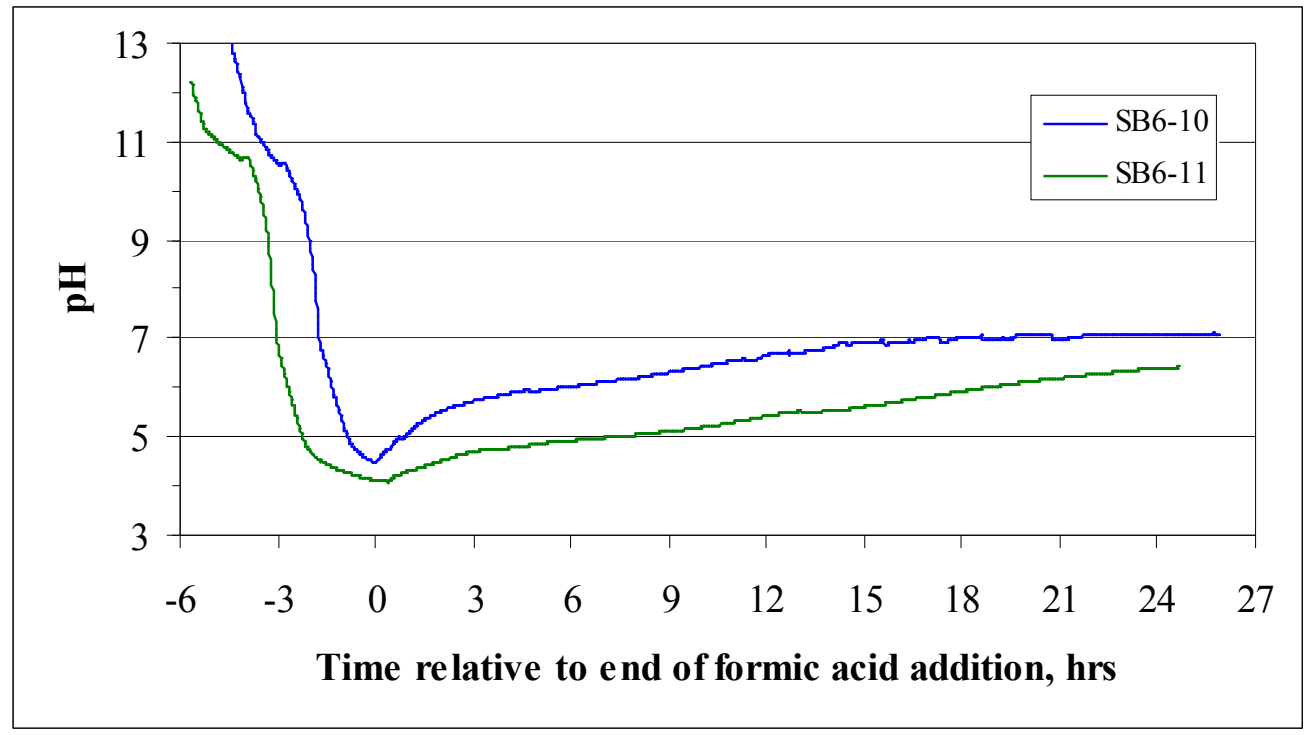

Figure 8. The pH profiles of the two SRAT cycles

The $\mathrm{pH}$ data for SB6-10 suggest a fairly sustained rate of attack on formic acid during reflux that tapered off as the $\mathrm{pH}$ approached seven. The $\mathrm{pH}$ data for SB6-11 also suggest a sustained rate of attach on formic acid that was on-going at the end of the SRAT cycle. 


\subsection{CONCLUSIONS}

Two SRAT runs were sufficient to demonstrate that a fairly wide window of acid stoichiometry was available for processing SB6 Phase II flowsheet simulant while still meeting the dual goals of acceptable nitrite destruction and controlled hydrogen generation. A window of about $50 \%$ in total acid exists between acceptable nitrite destruction and too much hydrogen generation.

The Phase II composition included very high mercury concentrations $(3.5 \mathrm{wt} \%$ in the total solids) combined with high noble metal concentrations. The higher acid stoichiometry test slurry was depleted of mercury faster than the lower stoichiometry, but it also produced a significant amount of ammonium ion (at least $20 \%$ of the nitrate in the system was converted to ammonium ion). Ammonia lost in the off-gas could not be quantified with the existing equipment. Significant mercury went unaccounted for in the high acid run ( $68 \%)$ and may have been lost in the off-gas or trapped in the SRAT vessel away from the bulk slurry being sampled.

The vast majority of the ammonium found in the high acid run stayed in the SRAT slurry which remained acidic throughout the SRAT cycle. This fact suggests that most of the ammonium could end up in the melter feed. The likely form is the ammonium ion rather than dissolved ammonia gas, since sustained boiling should have driven off dissolved gases in the SRAT slurry. A comparison of the Phase II data with past data suggests that mercury is catalyzing or otherwise promoting formation of the ammonium ion. The lower acid stoichiometry run produced much less ammonium ion based on the FAVC condensate result, but it failed to successfully strip the mercury to $0.45 \mathrm{wt} \%$ in the SRAT product total solids during 25 hours of boiling. 


\subsection{PATH FORWARD}

SB6 Phase III flowsheet studies are planned using improved bulk composition, mercury, and noble metal targets. It is planned to expand the sampling associated with mercury and ammonium during these tests. In addition, lab-scale ammonia scrubbers are being purchased to put in the off-gas line to absorb the ammonia into solution for quantification. 


\subsection{REFERENCES}

${ }^{1}$ Bricker, J.M., Sludge Batch 6 Flowsheet Studies, HLW-DWPF-TTR-2008-0043, Rev. 0, Savannah River Site, Aiken, SC 29808 (2008).

2 Lambert, D.P., Sludge Batch 6 Simulant Flowsheet Studies, SRNL-RP-2008-01341, Rev. 0, Savannah River Site, Aiken, SC 29808 (2009).

${ }^{3}$ Lambert, D. P., B. R. Pickenheim, and D. R. Best, DWPF SB6 Initial CPC Flowsheet Testing SB6-1 to SB6-6 4L Tests of SB6-A and SB6-B Simulants, SRNL-STI-2009-00413, Rev. 0, Savannah River Site, Aiken, SC, 29803 (July 2009).

4 Manual L29, Procedure ITS-00124, Rev 2, SRS HLW Sludge Simulant Preparation Savannah River Site, Aiken, SC 29808 (2008).

5 Manual L29, Procedure ITS-00094, Rev. 3, Laboratory Scale Chemical Process Cell Simulations, Savannah River Site, Aiken, SC 29808 (2006).

6 Koopman, D.C., A.I. Fernandez, B.R. Pickenheim, Preliminary Evaluations of Two Proposed Stoichiometric Acid Equations, Revision 0, SRNL-L3100-2009-00146, Savannah River Site, Aiken, SC 29808 (2009).

${ }^{7}$ Marek, J. C. and R. E. Eibling, Calculational Algorithms for Nitric Acid Sludge Adjustment, SRTC-PTD-92-0050, Savannah River Site, Aiken, SC, 29808 (September 1992).

8 Jantzen, C. M. and M. E. Stone, Role of Manganese Reduction/Oxidation (RedOx) on Foaming and Melt Rate in High Level Waste Melters, WSRC-STI-2006-00066, Savannah River Site, Aiken, SC, 29808 (March 2007).

${ }^{9}$ Koopman, D. C., DWPF Catalytic Hydrogen Generation Program - Review of Current Status, SRNL-STI-2009-00214, Savannah River Site, Aiken, SC, 29808 (July 2009).

${ }^{10}$ Koopman, D. C. Comparison of Dow Corning 544 Antifoam to IIT747 Antifoam in the 1/240 ${ }^{\text {th }}$ SRAT, WSRC-TR-99-00377, Savannah River Site, Aiken, SC, 29808 (December 1999).

${ }^{11}$ Koopman, D. C. and D. R. Best, Sludge Batch 6/Tank 51 Simulant Chemical Process Cell Simulations, SRNS-STI-2010-, Savannah River Site, Aiken, SC, 29808 (March 2010).

${ }^{12}$ Lambert, D.P., M. E. Stone, B. R. Pickenheim, D. R. Best, D. C. Koopman, Sludge Batch 5 Simulant Flowsheet Studies, SRNS-STI-2008-00024, Rev. 0, Savannah River Site, Aiken, SC, 29808 (2008). 
${ }^{13}$ Koopman, D. C. and D. P. Lambert, Initial Characterizations and SRAT Simulations of four Sludge Matrix Study Simulants, SRNL-STI-2009-00606, Rev. 0, Savannah River Site, Aiken, SC, 29808 (December 2009).

14 Koopman, D. C., D. R. Best, and B. R. Pickenheim, SRAT Chemistry and Acid Consumption during Simulated DWPF Melter Feed Preparation, WSRC-STI-2008-00131, SRNL, Aiken, SC, 29808 (December 2008).

${ }^{15}$ Lambert, D. P., M. E. Stone, B. R. Pickenheim, D. R. Best, and D. C. Koopman, Sludge Batch 5 Simulant Flowsheet Studies, SRNS-STI-2008-00024, Savannah River Site, Aiken, SC, 29808 (October 2008). 


\section{Distribution:}

S. L. Marra, 773-A

A. B. Barnes, 999-W

D. A. Crowley, 773-43A

S. D. Fink, 773-A

B. J. Giddings, 786-5A

C. C. Herman, 999-W

F. M. Pennebaker, 773-42A

J. E. Occhipinti, 704-S

D. C. Sherburne, 704-S

R. T. McNew, 704-27S

J. F. Iaukea, 704-30S

J. W. Ray, 704-S

H. B. Shah, 766-H

J. M. Gillam, 766-H

B. A. Hamm, 766-H

D. D. Larsen, 766-H

C. J. Bannochie, 773-42A

D. K. Peeler, 999-W

N. E. Bibler, 773-A

C. M. Jantzen, 773-A

M. E. Stone, 999-W

J. M. Pareizs, 773-A

S. H. Reboul, 773-A

J. M. Bricker, 704-27S

T. L. Fellinger, 704-26S

E. W. Holtzscheiter, 704-15S

M. T. Keefer, 766-H

B. R. Pickenheim, 999-W

D. P. Lambert, 999-W

J. D. Newell, 999-W

A. I. Fernandez, 999-W

D. R. Best, 999-W 